\title{
Path Analysis on Factors Affecting the Decision to Choose School of Acupuncture
}

\author{
Imrok Atus Sholihah'), Hanung Prasetya ${ }^{2)}$, Vitri Widyaningsih3) \\ 1)Masters Program in Public Health, Universitas Sebelas Maret, Surakarta \\ ${ }^{2)}$ Health Polytechnics, Ministry of Health, Surakarta \\ 3)Faculty of Medicine, Universitas Sebelas Maret
}

\section{ABSTRACT}

Background: Many universities offer various interesting educational programs. This makes prospective students faced with the situation to choose the programs appropriately according to their interests and talents. Prospective students have different considerations and reasons in choosing and deciding on acupuncture education as a place to continue their education. The purpose of this study was to analyze the factors that influence student decision making in choosing acupuncture education in Indonesia.

Subjects and Method: This was a case control study conducted at Health Polytechnic Ministry of Health Surakarta, Health Polytechnic Soepraoen Malang, and Acupuncture Academy Surabaya, in November 2019. A sample of 300 college students was selected by stratified random sampling. The dependent variable was decision to choose school of acupuncture. The independent variables were aspiration, attitude, career guidance, academic program, tuition fees, college reputation, promotion, facilities, financial assistance, location, and parental support. The data were collected by questionnaire and analyzed by path analysis run on Stata 13.

Results: College students who chose school of acupuncture was directly increased by good school reputation $(b=2.37 ; 95 \% \mathrm{CI}=0.77$ to 3.97 ; $\mathrm{p}=0.004)$, good career guidance $(\mathrm{b}=2.96 ; 95 \%$ $\mathrm{CI}=1.35$ to 4.58 ; $\mathrm{p}<0.001$ ), good education pro- grams $(b=2.46 ; 95 \% \mathrm{CI}=0.94$ to $3.97 ; \mathrm{p}=0.001)$, strong parental support $(\mathrm{b}=3.29 ; 95 \% \mathrm{CI}=1.75$ to 4.83; $\mathrm{p}<0.001)$, good financial assistance $(\mathrm{b}=$ 3.12; $95 \% \mathrm{CI}=1.49$ to $4.75 ; \mathrm{p}<0.001)$, good promotion $(\mathrm{b}=1.80 ; 95 \% \mathrm{CI}=0.34$ to $3.26 ; \mathrm{p}=$ 0.016), low tuition fees ( $b=2.48$; CI $95 \%=0.99$ to 3.97; $\mathrm{p}=0.001)$, and supportive location $(\mathrm{b}=$ 2.26; $95 \% \mathrm{CI}=0.85$ to $3.66 ; \mathrm{p}=0.002$ ). College students who chose school of acupuncture was indirectly affected by aspiration, attitude, and facilities.

Conclusion: College students who chose school of acupuncture is directly increased by good school reputation, good career guidance, good education programs, strong parental support, good financial assistance, good promotion, low tuition fees, and supportive location. College students who chose school of acupuncture is indirectly affected by aspiration, attitude, and facilities.

Keywords: decision making, acupuncture education, path analysis

\section{Correspondence:}

Imrok Atus Sholihah. Masters Program in Public Health, Universitas Sebelas Maret. Jl. Ir. Sutami 36A, Surakarta, Central Java. Email: imrokatussholihah6@gmail.com. Mobile: +6281225210252.

Cite this as:

Sholihah IA, Prasetya H, Widyaningsih V (2020). Path Analysis on Factors Affecting the Decision to Choose School of Acupuncture. J Health Policy Manage. 5(2): 127-138. https://doi.org/10.26911/thejhpm.2020.05.02.05 cc) () (2) Journal of Health Policy and Management is licensed under a Creative Commons Attribution-Non Commercial-Share Alike 4.o International License. 


\section{BACKGROUND}

Education is one way to improve the standard of living and quality of life of people, with education a person is able to develop interest in his talents and abilities in both academic and non-academic fields. The benefits of education in the long run can be felt by preparing quality human resources through quality education channels in the future, of course the nation must make the maximum investment to improve the quality of education and human resources (Artini et al., 2014).

Nowadays it is widely developed in the field of medical science and health based holistic medicine and reducing the use of chemicals, treatments that are highly developed in many countries such as the science of acupuncture therapy (Jishun and Mittelman, 2014). Decision making is the selection of several alternatives available as a tool to solve problems. Decision-making also means a systematic approach to a problem, gathering facts and data, determining the mature of the alternatives faced and taking action which according to the calculation is the most appropriate action (Eidimtas and Juceviciene, 2014).

Prospective students have different considerations and reasons in choosing and deciding on acupuncture education as a place to continue their education. A study by Mehboob (2012) explains that there are 11 aspects or factors that influence when choosing a tertiary institution, namely aspiration, attitude, career guidance, academic program, tuition fee, tertiary reputation, promotion, facilities, availability of financial assistance, location, and parental factors.

\section{SUBJECTS AND METHOD}

\section{Study Design}

This was analytic observational study with a case control design. The study was conducted at Health Polytechnic Ministry of Health
Surakarta, Health Polytechnic Soepraoen Malang, and Surabaya Academy of Acupuncture, in November 2019.

\section{Population and Sample}

The study population was college students. A sample of 300 college students was selected for this study by stratified random sampling.

\section{Study Variables}

The dependent variable was decision to choose school of acupuncture. The independent variables were aspiration, attitude, career guidance, academic program, tuition fee, college reputation, promotion, facilities, financial assistance, location, and parental support.

\section{Operational Definition of Variables Decision making was the result of actions} in taking a decision from various alternatives to achieve the desired goals. The measuring instrument used was a questionnaire. The measurement scale was categorical. Code $\mathrm{O}=$ non acupuncture and $1=$ acupuncture.

Aspiration was the desire for something higher with progress as its goal. The measuring instrument used was a questionnaire. The measurement scale was continuous and transformed into dichotomous. Code $\mathrm{O}=$ weak and $1=$ strong.

Attitude was the driving force or motivation that determines whether people have pros or cons of something. The data were measured by questionnaire. The measurement scale was continuous and transformed into dichotomous, coded $\mathrm{o}=$ weak and $1=$ strong.

Career guidance was a process of assistance given to an individual through various ways and forms of service so that he is able to plan his career steadily, according to his talents, interests, and abilities, knowledge and personality. The data were measured by questionnaire. The measurement scale was continuous and transformed into dichotomous, coded $\mathrm{o}=$ less and $1=$ good .

Educational program was higher education programs which are directed primarily 
at mastering science and its development, and prioritizing quality improvement and broadening scientific insights. The data were measured by questionnaire. The measurement scale was continuous and transformed into dichotomous, coded $\mathrm{O}=$ less and $1=$ good.

Education tuition was one of the components of instrumental input which is very important in the administration of education. In the form of education registration fees, student activity costs and book purchase costs. The data were measured by questionnaire. The measurement scale was continuous and transformed into dichotomous, coded $0=$ expensive and $1=$ cheap.

School reputation was an image drawn from an educational institution that is formed on people's thinking about the institution. The data were measured by questionnaire. The measurement scale was continuous and transformed into dichotomous, coded $\mathbf{0}=$ less and $\mathbf{1}=$ good .

Promotion was communication made by the product or service provider to the market to convey information about the product or service offered and has the nature to persuade and influence in order to convince potential customers to buy or use the services offered. The data were measured by questionnaire. The measurement scale was continuous and transformed into dichotomous, coded $\mathrm{o}=$ less and $\mathbf{1}=$ good.

Facilities were all facilities and infrastructures available to facilitate and support learning activities. The data were measured by questionnaire. The measurement scale was continuous and transformed into dichotomous, coded $\mathrm{O}=$ inadequate and $\mathbf{1}=$ adequate.

Financial assistance was assistance for students who have an important role in helping the smooth running of education for their children and to continue their education in college. The data were measured by question- naire. The measurement scale was continuous and transformed into dichotomous, coded $\mathrm{o}=$ not available and $1=$ available .

Location was a strategic position related to the ease of access and distance to or from the tertiary institution. The data were measured by questionnaire. The measurement scale was continuous and transformed into dichotomous, coded $\mathrm{O}=$ not support and $1=$ support.

Parental support was parental support by treating, guiding, educating, directing, disciplining and maturing children in making decisions to choose educational programs. The data were measured by questionnaire. The measurement scale was continuous and transformed into dichotomous, coded $\mathrm{O}=$ weak and $1=$ strong.

\section{Data Analysis}

Authors conducted data analysis and statistical tests on the results of study which included univariate analysis to describe each dependent and independent variable and grouped according to the type of data and entered. Bivariate analysis is performed using chi square which is to find out the relationship of each independent variable to the dependent variable. Multivariate analysis was performed using a path analysis model, an analysis technique used to determine the effect of exogenous variables on endogenous variables (both directly and indirectly).

\section{Research Ethic}

This study was conducted based on research ethics, namely informed consent, anonymity, confidentiality, and ethical eligibility. Ethics permit in this study was obtained from the Health Research Ethics Commission Dr. Moewardi, Surakarta, Indonesia, No. 1,285/ XII/ HREC/ 2019.

\section{RESULTS}

1. Sample Characteristics

The sample characteristic describes the continuous data presents in Table 1. 
Sholilah et al./ Path Analysis on Factors Affecting the Decision

Table 1. Sample characteristics (continuous data)

\begin{tabular}{lccccc}
\hline \multicolumn{1}{c}{ Variable } & n & Mean & SD & Min. & Max. \\
\hline Aspiration & 300 & 5.88 & 1.73 & 2 & 9 \\
Attitude & 300 & 5.93 & 1.52 & 3 & 9 \\
Career Guidance & 300 & 8.55 & 1.98 & 3 & 12 \\
Education programs & 300 & 5.95 & 1.89 & 2 & 9 \\
Cost of education & 300 & 7.67 & 1.92 & 3 & 12 \\
College reputation & 300 & 8.53 & 1.36 & 3 & 12 \\
Promotion & 300 & 7.73 & 2.05 & 3 & 12 \\
Financial Aid & 300 & 6.59 & 1.94 & 3 & 11 \\
Parental Support & 300 & 5.79 & 1.68 & 2 & 9 \\
Location & 300 & 5.35 & 1.58 & 2 & 9 \\
Amenities & 300 & 5.76 & 1.78 & 2 & 9 \\
\hline
\end{tabular}

\section{Univariate Analysis}

Table 2 shows that of the 300 students, the majority of strong aspirations were 163 (54.33\%). Strong attitude is 165 (55.00\%). Good career guidance is 164 (54.67\%). The good education program is 161 (53.67\%). The cost of education as much as expensive is 155
(51.67\%). Good university reputation is 160 (53.33\%). Less promotion is 141 (47.00\%) and good promotion is 159 (53.00\%). Weak parental support is 155 (51.67\%). Available financial assistance is 164 (54.67\%). Supporting locations are 157 (52.33\%). Inadequate facilities are 196 (65.33\%).

Table 2. Univariate analysis of the determinants of student decision making choosing acupuncture education

\begin{tabular}{|c|c|c|c|}
\hline Variable & Category & $\mathbf{N}$ & Percentage (\%) \\
\hline \multirow[t]{2}{*}{ Aspiration } & Weak (score< 6) & 137 & 45.67 \\
\hline & Strong (score $\geq 6$ ) & 163 & $54 \cdot 33$ \\
\hline \multirow[t]{2}{*}{ Attitude } & Weak $($ score $<6)$ & 135 & 45.00 \\
\hline & Strong (score $\geq 6$ ) & 165 & 55.00 \\
\hline \multirow[t]{2}{*}{ Career guidance } & Lacking (score< 9 ) & 136 & $45 \cdot 33$ \\
\hline & Good (score $\geq 9$ ) & 164 & 54.67 \\
\hline \multirow[t]{2}{*}{ Educational Program } & Lacking $($ score $<6)$ & 139 & 46.33 \\
\hline & Good (score $\geq 6)$ & 161 & 53.67 \\
\hline \multirow[t]{2}{*}{ Education tuition } & Expensive $($ score $<7)$ & 155 & 51.67 \\
\hline & Cheap (score $\geq 7$ ) & 145 & 48.33 \\
\hline \multirow[t]{2}{*}{ College reputation } & Lacking (score $<9$ ) & 140 & 46.67 \\
\hline & Good (score $\geq 9$ ) & 160 & 53.33 \\
\hline \multirow[t]{2}{*}{ Promotion } & Lacking (score < 8) & 141 & 47.00 \\
\hline & Good $($ score $\geq 8)$ & 159 & 53.00 \\
\hline \multirow[t]{2}{*}{ Parental Support } & Weak $($ score $<6)$ & 155 & 51.67 \\
\hline & Strong (score $\geq 6$ ) & 145 & 48.33 \\
\hline \multirow[t]{2}{*}{ Financial help } & Unavailable $($ score $<7)$ & 136 & $45 \cdot 33$ \\
\hline & Available (score $\geq 7$ ) & 164 & 54.67 \\
\hline \multirow[t]{2}{*}{ Location } & Unsupportive $($ score $<5)$ & 143 & 47.67 \\
\hline & Supportive (score $\geq 5$ ) & 157 & 52.33 \\
\hline \multirow[t]{2}{*}{ Facilities } & Unavailable $($ score $<6)$ & 196 & 65.33 \\
\hline & Available (score $\geq 6$ ) & 104 & 34.67 \\
\hline
\end{tabular}

Table 3 shows the results of the bivariate analysis of factors that increase the decision making of students choosing acupuncture education are strong career guidance $(\mathrm{OR}=$
7.78; p <0.001), good education programs $(\mathrm{OR}=30.60 ; \mathrm{p}<0.001)$, low tuition fees $(\mathrm{OR}=6.42 ; \mathrm{p}<0.001)$, good college reputation $(\mathrm{OR}=17.91 ; \mathrm{p}<0.001)$, good 
education promotion $(\mathrm{OR}=15.67 ; \mathrm{p}<0.001)$, strong parental support $(\mathrm{OR}=58.5$; $\mathrm{p}<0.001)$, financial assistance available $(\mathrm{OR}=$
3.82; $\mathrm{p}<0.001)$, supportive location ( $\mathrm{OR}=$ 20.15; $\mathrm{p}<0.001)$, and adequate tertiary facilities $(\mathrm{OR}=1.42 ; \mathrm{p}=0.150)$.

\section{Bivariate Analysis}

Table 3. The results of the chi-square test determinant of student decision making in choosing acupuncture education

\begin{tabular}{|c|c|c|c|c|c|c|}
\hline \multirow{3}{*}{ Independent Variable } & \multicolumn{4}{|c|}{$\begin{array}{l}\text { Decision making to choose } \\
\text { acupuncture education }\end{array}$} & \multirow{3}{*}{ OR } & \multirow{3}{*}{$\mathbf{p}$} \\
\hline & \multicolumn{2}{|c|}{ No } & \multicolumn{2}{|c|}{ Yes } & & \\
\hline & $\mathbf{N}$ & \% & $\mathbf{n}$ & \% & & \\
\hline \multicolumn{7}{|l|}{ Aspiration } \\
\hline Weak $($ score $<6)$ & 131 & 95.62 & 6 & 4.38 & 165.47 & $<0.001$ \\
\hline Strong (score $\geq 6$ ) & 19 & 11.66 & 144 & 88.34 & & \\
\hline \multicolumn{7}{|l|}{ Attitude } \\
\hline Weak $($ score $<6)$ & 117 & 86.67 & 18 & 13.33 & 26 & $<0.001$ \\
\hline Strong (score $\geq 6$ ) & 33 & 20.00 & 132 & 80.00 & & \\
\hline \multicolumn{7}{|l|}{ Career guidance } \\
\hline Lacking (score< 9) & 103 & $75 \cdot 74$ & 33 & 24.26 & 7.78 & $<0.001$ \\
\hline Good (score $\geq 9$ ) & 47 & 28.66 & 117 & 71.34 & & \\
\hline \multicolumn{7}{|l|}{ Educational Program } \\
\hline Lacking $($ Score $<6)$ & 121 & 87.05 & 18 & 12.95 & 30.60 & $<0.001$ \\
\hline Good (Score $\geq 6$ ) & 29 & 18.01 & 132 & 81.99 & & \\
\hline \multicolumn{7}{|l|}{ Education tuition } \\
\hline Expensive (score < 7) & 110 & 70.97 & 45 & 29.03 & 6.42 & $<0.001$ \\
\hline Cheap (score $\geq 7$ ) & 40 & 27.59 & 105 & 72.41 & & \\
\hline \multicolumn{7}{|l|}{ College reputation } \\
\hline Lacking (score< 9) & 116 & 82.86 & 24 & 17.14 & 17.91 & $<0.001$ \\
\hline Good (score $\geq 9$ ) & 34 & 21.25 & 126 & 78.75 & & \\
\hline \multicolumn{7}{|l|}{ Promotion } \\
\hline Lacking (score < 8) & 115 & 81.56 & 26 & 18.44 & 15.67 & $<0.001$ \\
\hline Good (score $\geq 8$ ) & 35 & 22.01 & 124 & 77.99 & & \\
\hline \multicolumn{7}{|l|}{ Parental support } \\
\hline Weak $($ score $<6)$ & 135 & 87.10 & 20 & 12.90 & 58.5 & $<0.001$ \\
\hline Strong (score $\geq 6$ ) & 15 & 10.34 & 130 & 89.66 & & \\
\hline \multicolumn{7}{|l|}{ Financial assistance } \\
\hline Unavailable (score < 7) & 92 & 67.65 & 44 & 32.35 & 3.82 & $<0.001$ \\
\hline Available (score $\geq 7$ ) & 58 & $35 \cdot 37$ & 106 & 64.63 & & \\
\hline \multicolumn{7}{|l|}{ Location } \\
\hline Unsupportive (score < 5) & 119 & 83.22 & 24 & 16.78 & 20.15 & $<0.001$ \\
\hline Supportive (score $\geq 5$ ) & 31 & 19.75 & 126 & 80.25 & & \\
\hline \multicolumn{7}{|l|}{ Facilities } \\
\hline Unavailable (score< 6) & 104 & 53.06 & 92 & 46.94 & 1.42 & 0.150 \\
\hline Available (score $\geq 6$ ) & 46 & 44.23 & 58 & 55.77 & & \\
\hline
\end{tabular}

\section{Multivariate Analysis}

Table 4 shows that there is a direct effect on the reputation of tertiary institution, career guidance, educational program, parental support, financial assistance, promotion, education fee, and location on the decision making of students choosing acupuncture education. A good college reputation $(b=2.37 ; 95 \% \mathrm{CI}=$ 0.77 to $3.97 ; \mathrm{p}=0.004)$. Good career guidance $(b=2.96 ; 95 \% \mathrm{CI}=1.35$ to $4.58 ; \mathrm{p}$ $<0.001)$. Good education program ( $\mathrm{b}=2.46$; $95 \% \mathrm{CI}=0.94$ to $3.97 ; \mathrm{p}=0.001$ ). 
Sholilah et al./ Path Analysis on Factors Affecting the Decision

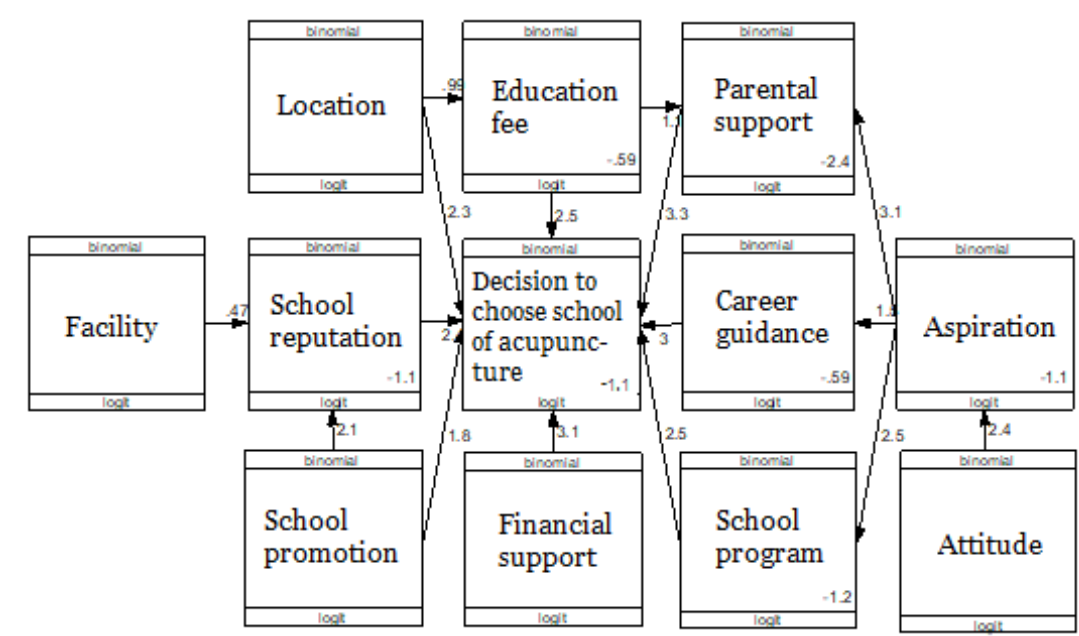

Figure 1. Path analysis model on the decision to choose school of acupuncture

Table 4. Path analysis on the determinants of college student decision to choose school of acupuncture

\begin{tabular}{|c|c|c|c|c|c|}
\hline \multirow[b]{2}{*}{ Dependent Variable } & \multirow[b]{2}{*}{ Independent Variable } & \multirow[b]{2}{*}{$\begin{array}{c}\text { Path } \\
\text { Coef. (b) }\end{array}$} & \multicolumn{2}{|c|}{ 95\% CI } & \multirow[b]{2}{*}{$\mathbf{p}$} \\
\hline & & & $\begin{array}{l}\text { Lower } \\
\text { Limit }\end{array}$ & $\begin{array}{l}\text { Upper } \\
\text { Limit }\end{array}$ & \\
\hline \multicolumn{6}{|l|}{ Direct Effect } \\
\hline \multirow[t]{8}{*}{ Decision making } & School reputation (good) & 2.37 & 0.77 & 3.97 & 0.004 \\
\hline & Career guidance (good) & 2.96 & 1.35 & 4.58 & $<0.001$ \\
\hline & School program (good) & 2.46 & 0.94 & 3.97 & 0.001 \\
\hline & Parental support (strong) & 3.29 & 1.75 & 4.83 & $<0.001$ \\
\hline & Financial guidance (available) & 3.12 & 1.49 & 4.75 & $<0.001$ \\
\hline & School promotion (strong) & 1.80 & 0.34 & 3.26 & 0.016 \\
\hline & Education fee (low) & 2.48 & 0.99 & 3.97 & 0.001 \\
\hline & Location (supportive) & 2.26 & 0.85 & 3.66 & 0.002 \\
\hline \multicolumn{6}{|l|}{ Indirect Effect } \\
\hline \multirow[t]{2}{*}{ School reputation } & Promotion (good) & 2.07 & 1.55 & 2.59 & $<0.001$ \\
\hline & Facilities (available) & 0.47 & -0.08 & 1.02 & 0.093 \\
\hline Career guidance & Aspiration (good) & 1.46 & 0.97 & 1.94 & $<0.001$ \\
\hline Educational Program & Aspiration (good) & 2.52 & 1.97 & 3.07 & $<0.001$ \\
\hline \multirow[t]{2}{*}{ Parental Support } & Aspiration (good) & 3.09 & 2.45 & 3.74 & $<0.001$ \\
\hline & Tuition (cheap) & 1.14 & 0.52 & 1.76 & $<0.001$ \\
\hline Tuition & Location (supportive) & 0.99 & 0.52 & 1.46 & $<0.001$ \\
\hline Aspiration & Attitude (positive) & 2.37 & 1.83 & 2.90 & $<0.001$ \\
\hline Constanta & & -10.91 & -14.63 & -7.19 & $<0.001$ \\
\hline
\end{tabular}

n observation $=300$

education is influenced indirectly by aspira-

Strong parental support $(b=3.29 ; 95 \% \mathrm{CI}=$ 1.75 to $4.83 ; \mathrm{p}<0.001)$. Financial assistance available $(b=3.12 ; 95 \% \mathrm{CI}=1.49$ to 4.75 ; $\mathrm{p}<0.001)$. Good promotion $(\mathrm{b}=1.80 ; 95 \%$ $\mathrm{CI}=0.34$ to $3.26 ; \mathrm{p}=0.016)$. Low cost of education $(b=2.48 ; 95 \% \mathrm{CI}=0.99$ to $3.97 ; \mathrm{p}=$ o.001). Supporting locations $(b=2.26 ; 95 \%$ $\mathrm{CI}=0.85$ to $3.66 ; \mathrm{p}=0.002$ ). Decision making of students choosing acupuncture tions, attitudes, and facilities.

\section{DISCUSSION
1. The effect of college reputation on the decision to choose school of acu- puncture}

These results indicate that a good college reputation increases student decision making in choosing acupuncture education. Higher 
education's reputation comes from ranking, which reflects a good reputation built on age, accreditation and acceptance competitiveness and brand names (Haron et al., 2017).

These results are consistent with Kusumawati (2010), which reported that out of 342 respondents $(80.28 \%)$ agree that the reputation of tertiary institutions is an important factor in choosing education. It is believed that the more a college has a reputation, the higher the chance to get a job easily after graduation or the higher the guarantee for students to get high paid jobs after graduation (Proboyo and Soedarsono, 2015).

Many studies have shown that university student choice decisions are influenced by university attributes. These attributes are identified as quality of staff, type of institution, availability of desired programs, curriculum, international reputation, quality of facilities such as libraries, computerized and social facilities, campus and class sizes and availability of financial assistance (Aydin, 2015).

2. The effect of career guidance on the decision to choose school of acupuncture

These results indicate that the influence of good career guidance increases the decision making of students choosing acupuncture education. This study is consistent with previous study that the presence of a career counseling and guidance office $(r=0.672)$ shows the first supporting factor in making decisions in choosing college education (Agrey and Lampadan, 2014). Academic aspirations and career guidance can inform policy makers and educators about the best way to provide support at the community and school level to facilitate the transition of students from school to further education and work (Tsui et al., 2019).

3. The effect of educational programs on the decision to choose school of acupuncture
These results indicate that a good education program increases the decision making of students choosing acupuncture education. Price and Agahi (2003) explain that the study program offered and the reputation of higher education are important factors when choosing a university in the UK for students (Haryanti et al., 2016). In general, prospective students consider study programs before they consider which university will be registered (Susilawati et al., 2019).

The program structure contains information content and learning methodologies for certain programs in higher education. The content and structure of the program is controlled, revised, and monitored from time to time by each tertiary institution to ensure high quality (Haron et al., 2017).

\section{The effect of parental support on the decision to choose school of acu- puncture}

These results indicate strong parental support to improve student decision making in choosing acupuncture education. Shanka et al. (2005) explain that family influence is a major factor in the choice of higher education. Because almost all students consult with their parents about their higher education plans (Aydin, 2015). Aguado et al. (2015) explained parents are the financiers of the education of their children, they have a significant influence on their children choosing higher education (Rudhumbu, 2017). Decision making of students choosing acupuncture education is influenced by families after trying acupuncture therapy (Purwanto et al., 2016).

\section{The effect of financial assistance on the decision to choose school of acupuncture}

These results indicate the financial assistance available increases student decision making in choosing acupuncture education. Sojkin et al. (2012) explained that reputation offers tuition fees and access to financial assistance 
to prospective students (Haryanti et al., 2016). So and Hyun (2015) distinguish between financial assistance and tuition. Financial assistance acts as an aid to fund student education costs i.e. financial assistance can come from many sources (Haron et al., 2017). As an example; can be obtained from the government, the college itself or foundation and can come in various forms such as loans, scholarships and grants (Rika et al., 2016).

\section{The effect of school promotion on the decision to choose school of acupuncture}

This result shows that good promotion enhances student decision making in choosing acupuncture education. Media such as television, newspapers and magazines are used by universities to advertise or promote. This includes information about education, social facilities, contact information or employment prospects. Media can be used by universities not only by advertising but also provides some information about their facilities (Aydin, 2015).

Previous study by Yun (2017) explains that information sources obtained from direct communication from institutions or universities, university websites, someone/alumni from universities, families, and brochures/ pamphlets about tertiary institutions are considered to be most beneficial for all students.

7. The effect of education fee on the decision to choose school of acupuncture

This result shows that the low cost of education increases student decision making in choosing acupuncture education. Previous study by Agrey et al. (2014) showed that 51\% of prospective students said the level of tuition was important in making decisions in choosing tertiary education (Agrey and Lampadan, 2014). Roushdy (2012) argues that the factors that influence students' decisions in choosing tertiary education can be divided into two categories: economic factors and non-economic factors. Economic factors include university tuition fees, availability of scholarships and grants, accommodation (rooms and lodgings). Whereas noneconomic factors are university size, and location (Islam and Shoron, 2020).

\section{The effect of school location on the decision to choose school of acu- puncture}

These results indicate a location that supports improving student decision making choosing acupuncture education. Padlee et al. (2010) explained that the location of higher education institutions influenced students to choose universities in Malaysia (Haryanti et al., 2016). This factor refers to the university's geographical location, and close to the city center or home. The location of the university and the geography of its environment are very important characteristics for students. Proximity to home is one of the significant effects on university choice processes (Aydin, 2015).

\section{The effect of school promotion on the decision to choose school of acupuncture through school repu- tation}

The results of this study indicate that there is a good promotional effect on the reputation of higher education. Higher education promotion in the form of printed brochure, advertisements, and web content (Krezel and Krezel, 2017).

Higher education has a planned promotion strategy to compete with other educational institutions. Marketing content that is well communicated from certain institutions will enhance the reputation of higher education and student registration. The decision of students in choosing a tertiary education institution in Malaysia, it was found that the promotion of tertiary reputation had a positive impact on study choices (Haron et al., 2017).

10. The effect of facilities on the deci- 
sion to choose school of acupuncture, through school reputation

These results indicate that there is no statistical effect of facilities on tertiary reputation. However, adequate facilities have the possibility of increasing the reputation of higher education. This study is in accordance with previous study by Haryanti et al. (2016) explain that the facility enhances the reputation of tertiary education and influences the choice of Chinese students in the UK. Educational facilities such as lecture halls, libraries, and laboratories also have an extraordinary effect on high school students in choosing a university (Haryanti et al., 2016).

College facilities consist of: (a) physical facilities such as the existence of bookstores, guidance and counseling offices; and (b) nonphysical facilities such as the provision of scholarships, the ability to transfer credit together with spiritual programming. The learning environment and job prospects can be explained in terms of having modern learning facilities and environments, a beautiful campus, developing and maintaining a good reputation, along with the number of books available in the library, a new computer lab and high levels of job prospects for graduates. Sports facilities might be explained in terms of campuses that have sports complexes and other good sports facilities (Agrey and Lampadan, 2014).

11. The effect of aspiration on the decision to choose school of acupuncture through career guidance These results indicate a strong aspiration to improve career guidance. The decision of students to choose tertiary education is influenced by three core factors, namely: desire, environment, and future career aspirations (Wu, 2014). Career guidance is guidance and experience determines career. Participants get support from a mentor and experience in their future roles to confirm that they are on the right career path. Many participants identified their career goals as working in higher education. They feel that during the education program helps in career planning. Furthermore, students' aspirations improve the decision to choose tertiary education based on the career guidance they get (Singe et al., 2019).

12. The effect of aspiration on the decision to choose school of acupuncture, through educational programs

These results indicate strong aspirations to improve education programs. Hooker and Brand (2009) examined 23 educational programs that function to prepare middle school students' aspirations and prepare for colleges/universities and have quality program evaluations. Study programs include academic support, relationships, college knowledge and access, relevance, youth-centered programs and effective teaching, as well as structural elements of success such as cross-system partnerships and collaborations, strategic use of time, leadership and effective assessment (Fischer et al., 2017). Evaluation of higher education study programs focusing on students supporting higher education aspirations (James-maceachern and Yun, 2017).

13. The effects of aspiration on the decision to choose school of acupuncture, through parental support

These results indicate strong aspirations of increasing parental support. Jüttler et al. (2016) reported that educational aspiration and parental support were significantly related (Jüttler et al., 2016). Students build aspirations and plans for university prospects based on parental guidance (Wu et al., 2014). In a longitudinal study they examined how practices related to emotional and cognitive involvement of parental support to AfricanAmerican and European-American children influence children's success and aspirations 
in subsequent years through enrollment in higher education (Fischer et al., 2017).

\section{Effects of educational fee on the decision to choose school of acu- puncture, through parental sup- port}

This result shows that the low cost of education increases parents' support. Previous study by Praboyo et al. (2015) shows that cost influences parental support in higher education choices (Proboyo and Soedarsono, 2015). Financial support from one's family can result in the limitation of his decisions regarding their academic future. If the tuition fees support, then the student's family has enough budget to pay for the child to graduate. Financial support from parents or family can limit the choice of college education (Aydin, 2015).

\section{The effect of location on the deci- sion to choose school of acupunc- ture, through education fees}

These results indicate a location that supports increasing education costs. The location of the college close to home influences the decision of high school students to choose tertiary institutions. This can reduce tuition and student living costs so as to support students' decision to choose tertiary institutions (Haryanti et al., 2016). Garwe (2016) explains that students can choose to study in universities close to their hometown to save transportation costs (Ha et al., 2017).

16. The effect of attitudes on the decision to choose school of acupuncture, through aspiration

These results indicate a strong attitude to increase the aspirations of students. Previous study by Wu and Bai (2014) showed that aspirations in choosing tertiary education were influenced by socio-economic attitude and value. Attitude is a factor that influences one's behavior and aspirations and thus knows what actions will be taken including decision making (Kartika et al., 2017). Some- one will do or not do a behavior based on previous considerations whether the attitude supports or does not support (Fitriani et al, 2016).

Ajzen (1991) explains the well-known psychological approach is the theory of planned behavior. This theory shows that three different aspects explain educational aspirations: attitudes (towards a behavior), subjective norms and perceived behavioral control. Knowledge and attitudes of students influence the aspirations of higher education. This increases the tendency of students to want to study in college (Jüttler et al., 2016)

\section{AUTHOR CONTRIBUTION}

Imrok Atus Sholihah as the main author plays a role in collecting data, processing data analysis, and writing the article. Hanung Prasetya plays a role in the formulation of the background. Vitri Widyaningsih plays a role in the formulation of the mindset and discussion of the topic.

\section{CONFLICT OF INTEREST}

There is no conflict of interest in this study.

\section{FUNDING AND SPONSORSHIP}

This study is self-funded.

\section{ACKNOWLEDGEMENT}

Our gratitude goes to the Director of the Polytechnic of the Ministry of Health Surakarta, Polytechnic Health Dr. Soepraoen Malang and Surabaya Academy of Acupuncture who have allowed this study to be carried out. Thank you to all students who have been willing and cooperative to become respondents.

\section{REFERENCE}

Agrey L, Lampadan N (2014). Determinant factors contributing to student choice in selecting a university. Journal of Education and Human Development: 3(2): 391-404. Retrieved from jehdnet- 
Sholilah et al./ Path Analysis on Factors Affecting the Decision

.com/journals/jehd/Vol_3_No_2_June_2014/22.pdf

Artini IDAJ, Kirya IK, Suwendra IW (2014). Faktor-faktor yang mempengaruhi keputusan mahasiswa dalam memilih jurusan di Fakultas Ekonomi dan Bisnis (FEB) Universitas Pendidikan Ganesha (Undiksha) sebagai tempat kuliah (Factors that influence students' decisions in choosing majors in the Faculty of Economics and Business (FEB) Ganesha University of Education (Undiksha) as a place of study). Jurnal Bisma Universitas Pendidikan Ganesha Jurusan Manajemen, 2(1): 1-8. Retrieved from http://ejournal.undiksha.ac.id/index.php/JJM/article/view/-3386

Aydin OT (2015). University choice process: a literature review on models and factors affecting the process. Yükseköretim Dergisi Journal of Higher Education, 5(2): 103-111. https://doi.org/10.2399/yod.15.008

Eidimtas A, Juceviciene P (2014). Factors influencing school-leavers decision to enrol in higher education. ProcediaSocial and Behavioral Sciences, 116: 3983-3988. https://doi.org/10.1016/j.sbspro.2014.01.877

Fischer S, Barnes RK, Kilpatrick S (2017). Equipping parents to support their children's higher education aspirations: a design and evaluation tool. Educational Review, 1911: 1-20. https://doi.org/10.1080/o0131911.2017.1379472

Fitriani Y, Tamtomo D, Sulaeman ES (2016). Path analysis on the determinants of the use of integrated health post and the application of Theory of Planned Behavior. J Health Promot Behav, 1(4): 228-237. http://dx.doi.org/10.26911/thejhpb.2016.01.04.02

Haron H, Hamid NAA, Jamaludin J, Azan KNK (2017). Students' decision factors in choosing private higher education institutions. International Journal of Academic Research in Business and Social Sciences, 7(11): 1372-1382. https://doi.org/10.6007/ijarbss/v7-i11/3576

Haryanti, Wijayanto H, Sumarwan U (2016). Analysis of the factors influencing bogor senior high school student choice in choosing Bogor Agricultural University (Indonesia) for further study. Journal of Education and ELearning Research, 3(3): 87-97. https://doi.org/10.20448/journal.509/2016.3.3/509.3.87.97

Islam MA, Shoron NH (2020). Factors influencing students' decision making in selecting university in Bangladesh. Advanced Journal Social Science, 6(1): 17-25. https://doi.org/10.21467/ajss.6.1.17-25

James-maceachern M, Yun D (2017). Exploring factors influencing international students' decision to choose a higher education institution: A comparison between Chinese and other students. International Journal of Education Management, 31(3): 343-363. https://doi.org/10.1108/IJEM-11-20150158

Jishun J, Mittelman M (2014). Acupuncture: past, present, and future. Glob Adv Health Med, 3(4): 6-8. https://doi.org/10.7453/gahmj.2014.042

Jüttler M, Jüttler A, Schumann S, Eberle F (2016). Work or university? Economic competencies and educational aspirations of trainees with hybrid qualifications in Switzerland. Empir Res Vocat Educ Train, 8(6): 1-26. https://doi.org/10.1186/s40461-016-0032-1

Kartika, Budihastuti UR, Pamungkasari EP (2017). Determinants of long-term contraceptive method use in madiun, east java: application of social cognitive theory. J Health Promot Behav, 02(04): 
Sholilah et al./ Path Analysis on Factors Affecting the Decision

313-322. https://doi.org/10.26911/thejhpb.2016.02.04.03

Krezel J, Krezel ZA (2017). Social influence and student choice of higher education institution. The Journal of Education, Culture, and Society, (2): 116-130. Https://doi.org/10.15503/jecs20172.116.130

Mehboob F (2012). Factors influencing student's enrollment decisions in selection of higher education institutions (Hei's). Interdisciplinary Journal of Contemporary Research in Business, 4(5): 558568. https://doi.org/ 10.4236/iim.2019.114006

Proboyo A, Soedarsono R (2015). Influential factors in choosing higher education institution: A case study of a private university. Jurnal Manajemen Pemasaran, 9(1): 1-7. https://doi.org/10.9744/pemasaran.9.1.1-7

Purwanto, Dharmawan R, Demartoto A (2016). Decision to choose acupuncture therapy for degenerative diseases among the elderly at Ja'far Medika. J Health Promot Behav, 1: 128-138. https://doi.org/10.26911/thejhpb.2016.01.02.08

Rika N, Roze J, Sennikova I (2016). Factors affecting the choice of higher education institutions by prospective students in Latvia. CBUNI, 422-430. https://doi.org/10.13140/RG.2.1.3238.1848

Rudhumbu N (2017). Factors that influence undergraduate students' choice of a university: A case of Botho University in. International Journal of Learning and Development, 7(2). https://doi.org/10.5296/ijld.v7i2.10577

Singe SM, Pike AM, Coleman KA, Myers SL, Barrett J, Belval LN, Rush JL, Katch RK (2019). Doctoral education in ath- letic training: pursuit of the degree and its influence on career aspirations doctoral education in athletic training: pursuit of the degree and its influence on career aspirations. Athl Train Educ J, 14(2): 99-107. https://doi.org/10.4085/140299

Susilawati W, Alamanda DT, Mustaqim Z, Ramdhani A (2019). Finding the recipe to improve the enrolment rate of higher education institution (HEI) in Garut Regency, Indonesia. Review of Integrative Business and Economics Research, 8(4): 264-274. Retrieved from http://buscompress.com/journalhome.html

Tsui K, Lee CJ, Hui KS, Chun WD, Chan NK (2019). Academic and career aspiration and destinations: a Hongkong perspective on adolescent transition. Hindawi Education Research International, 2019. https://doi.org/10.1155/2019/3421953

Wu C, Bai H (2014). From early aspirations to actual attainment: the effects on university pursuit. High Educ. https://doi.org/10.1007/s10734-014-9778-1

$\mathrm{Wu} \mathrm{Q}$ (2014). Motivations and decisionmaking processes of mainland Chinese students for undertaking master's programs abroad. Journal of Studies in International Education, 18(5): 426444. https://doi.org/10.1177/-1028315313519823

Yun MJD (2017). Exploring factors influencing international students' decision to choose a higher education institution: a comparison between Chinese and other students. International Journal of Educational Management, 31(3). https://doi.org/10.1108/IJEM-11-2015-0158 